\title{
Uzbek people in the resistance forces ranks during the second world war
}

\author{
Saidov Ilkhom Mukhiddinovich ${ }^{1}$ \\ ${ }^{l}$ D.h.sci. Prof. of «Historiography and source study» department of Samarkand State University \\ ilhomsaidov@mail.ru
}

\begin{abstract}
The article examines Uzbek fighters' heroic actions in the battles on the front line. Notoriously, that Uzbek thrillers were also at the fronts forefront organized against the Nazi army, which was waging aggressive wars to subjugate the whole world.
\end{abstract}

The unique archival documents and scientific literature that have survived to this day contain original information about Uzbek soldiers battles at the front. This article is also devoted to a scientific study of Uzbek soldiers heroism in major battles at the front which are based on these facts.

Keywords: front, geopolitics, frontispiece, partisans, resistance movement, liberation struggle, heroism, anti-fascist movement.

\section{INTRODUCTION}

Uzbek people as part of the USSR peoples took a prominent place in ensuring the decisive role of the Soviet Armed forces in defeating the enemy. Its role in other forms implementation of international assistance to Europe peoples was significant. Thus, Uzbekistan provided assistance to allied armies and the national military formations created on the USSR territory in training military personnel. In particular, in connection with the 1st Czechoslovak corps formation on the General staff directive basis on April 10, 1944 in Tashkent military schools, as well as in other schools of the country, were created Czech and Slovak nationality cadets branches. In Polish army from 16396 officers, temporarily detached from the Soviet army, about 8\% were Uzbeks. Two volunteer Romanian and Bulgarian divisions had more than 20 instructor- officers from Uzbekistan [1.44-48]. According to experts' estimates, more than 40 thousand Soviet citizens took part in partisan formations, underground-sabotage groups of European states [2.230].

Our compatriots took a significant share among them.

The emergence beginning of the mass Resistance movement in most European countries fell on 1941-1942. It had significant military-strategic and political importance for all participants in the anti-fascist struggle, as well as the USSR.

The Resistance actions, especially the partisan movement, not only inflicted huge human and material losses to the enemy, disorganized the various enterprises, transport work, disrupted the armies supply with necessary everything for conducting combat operations, but also diverted a significant number of combat divisions from the Soviet-German and other fronts to fight the patriots.

\section{MAIN PART}

The spontaneous participation of Soviet people in Europe peoples liberation struggle began to manifest itself already at the first stages of the Soviet-German war, when hundreds thousands of Red Army soldiers were taken prisoner for one reason or another, millions of civilians were forcibly driven by the Hitlerite to Germany from the temporarily occupied regions of the USSR . They were guarded, used in hard work, morally humiliated, severely punished. Tens thousands were shot, many died from hunger and disease. But, despite the extreme conditions, people did not leave the hope for freedom. Quite a few of them fled from detention and work places, grieving with the enemy hatred, joined various organizations waging a struggle against fascism. According to the historian V.A. Zamlinsky, the total number the war and civilians Soviet prisoners who fled from the camps alone was about 450 thousand [3.183].

A particularly great contribution was made by the "Soviet" people cut off from their homeland, including our fellow countrymen, at the initial stage of the war in the Resistance movement development in Poland. They fought in almost every partisan formation, and some were the organizers - commanders and staff chiefs of these detachments. According to Polish researchers' calculations, over 65 thousand Soviet citizens fled from the camps in Poland. A significant part of those who fled - more than 20 thousand managed to get in touch with the Polish underground and took an active part in the anti-fascist struggle [4.131]. They included many natives of Uzbekistan. For example [5.41], Saifulla Nurullaev from Samarkand, who escaped from enemy captivity, joined a partisan detachment operating in the Janovskie forests in the Lyublino region. In Jilenko group part, on June 7, 1944, he together with his fighting friends blew up 5 military echelons on the Lublin-Krasnik railway line. 50 were killed and to 140 were wounded and such examples were broad. The research materials clearly show that in the period 1941-1943, Uzbeks who escaped from captivity began to actively replenish the "resistance" ranks in all the European countries occupied by the Hitlerite. Thus, our fellow 
countrymen fought bravely on Yugoslav soil in Yugoslavia People's Liberation Army ranks; in Greece, Czechoslovakia, Albania, France, Italy, Norway, Hungary, Romania [6.273-278].

One of the first paratroopers groups of 10 people landed in southern Poland in the summer of 1944 and immediately established contact with local detachments of the Ludovoy Army. The group was called "Struggle" ("Valka"), which was constantly replenished with war prisoners who fled from the camps, later becoming a large partisan detachment. Galim Bulatov from Samarkand also fought in its ranks. Despite constant pursuits and round-ups, the detachment did not stop sabotage and reconnaissance activities, under its control were all enemy communications in the area south and south-west of Krakov.

On January 5, 1944, a raid on the enemy rear of the 1st Ukrainian partisan division under P.P. Vershigor command. From February 9 to March 18, on Poland territory, together with Polish partisans, she carried out a number of important military operations, during which 17 railway and highway bridges were blown up, as well as a military plant in Stalevaya Volya. In total, during the raid, the division covered 2,100 km, conducted 139 battles, in which 5,160 enemy soldiers and officers were killed, 598 were taken prisoner. The partisans blew up 24 enemy trains, destroyed 11 steam locomotives, 227 wagons and platforms, 75 tanks and armored vehicles, 196 vehicles, 5 aircraft, 30 enemy bunkers [7.57]. A significant contribution to ensuring the partisan high effectiveness raid was made by the Uzbek partisans. Only on N. Kulmatov and K. Bashirov personal account were 34 killed invaders and 2 destroyed machine-gun crews [8.1720]. A lot of Uzbek soldiers acted as sabotage and reconnaissance groups' part thrown into the enemy rear. For example, A.P. Sukhorukova from Samarkand, who, among one of the reconnaissance detachments, was transferred to Poland. The detachment established contact with a partisan detachment operating in the area and began collecting intelligence. The scouts, participated in partisans combat operations, assisted in organizing terrorist acts. An indispensable assistant in organizing these operations was the radio operator Anya Sukhorukova, who, despite the difficult combat conditions, provided stable radio communications [9.25-27].

From the second half of 1944, the Soviet command began to throw in groups to organize the partisan movement in droves. Thus, by the end of 1944, 53 organizing groups were transferred to Slovakia, 12 to Romania, and 11 to Hungary. These groups grew rapidly in number, turning over time into large partisan formations. For example, on June 26, 1944, the first organizing group sent to Czechoslovakia under the command of senior lieutenant P.A. Velichko, consisting of 9 people, landed in Nizkiy Tatr region. The guerrillas equipped the base and the landing site. By August, Velichko's group had increased to 300, and by the end of September there were 2080 fighters of more than 12 nationalities. The commander of one of the platoons was appointed an Uzbek citizen - Konstantin Danilov, who escaped from fascist captivity [10.10]. Subsequently, Danilov was entrusted with the detachment command. Here his talent as a commander was fully revealed. K.Danilov's detachment soon became one of the largest and most active combat formations, the number of soldiers in it reached four hundred [11]. At the end of 1944, the Ukrainian partisan movement staff appointed K. Danilov as the commander of the second partisan regiment in Slovakia, which distinguished itself during Slovak uprising days [12.100]. Some glorious military deeds were recorded on a personal account, who fought in Czechoslovakia partisans ranks, V.F. Melnikov, R. Alamov, A. Nazrullaev, R. Khamraev, A. Urazniyazov, A. Komikov and many other brave representatives of Uzbekistan [6.267-268].

Our fellow countrymen fought heroically in Yugoslavia. According to V.N. Kazak's estimates, at least 6100 Soviet citizens took part in the YPLA units and partisan formations on Yugoslav territories [13.73].

In fierce battles with elite fascist divisions on Slovenia, Bosnia, Herzegovina, Serbia, Macedonia territories, Lev Kalontarov and Galina Gritsenko from Samarkand, Uksanbay Khalmatov from Fergana, Kulmat Mamadaliev from Kattakurgan, Yu. F. Rijov from Tashkent, Mamatkhan Jalilov from Andijan and many other brave sons and daughters of Uzbekistan [6.270-272].

In 1943-1944 there were several thousand Soviet citizens in 35 fascist concentration camps in France. Many of them escaped and were actively involved in the liberation struggle of the French people. In the spring of 1944 in France, there were already 55 insurgent units and many small groups [14.191-192]. The natives of Uzbekistan also acted in their composition. Each of our fellow countrymen has shown boundless bravery, courage and heroism in the fight against the fascist invaders. Thus, the names of Uzbeks Rakhman Rakhimov, Sergey Petrov, Tadjibay Ziyaev, Andrey Ayrapetov, Khashim Ismailov and our other heroic fellow countrymen, marked by the French government with high awards for military deeds performed on French have forever entered the French resistance movement history [6.274-276].

For the battles near the village of Jukevil and for Karmo city, Kh. Ismailov was awarded with Jeanne dArc Cross. T. Ziyaev received the same award. In these battles, the fighters from Tashkent H. Jabarov, B. Sagdullaev, A. Gafurov, Koldashev and Alimov also distinguished themselves [15.134].

The feat born in the German concentration camps dungeons of the underground group of the famous hero Musa Jalil entered the Resistance movement chronicle of Europe peoples with golden letters, whose fighting comrades-in-arms were the brave sons of Uzbekistan - Fuat Sayfulmulukov, Garif Shabaev, Gali Kurbanov, Farit Sultanbekov, Garaf Fakhrutdinov [6.272-273].

\section{CONCLUSION}

Uzbeks imprisoned in the Kiel "forced labor" camps showed a high patriotic spirit. There were about 10 underground groups operating here, which included about 50 natives of Uzbekistan [16.10-12].

In general, the Uzbeks, participating in the Resistance forces ranks against fascism in European countries, showed selflessness and heroism, devotion examples to their people. In the most difficult conditions, they did not despond, they joined in an active struggle against the enemy, thereby bringing the Victory Day over Hitlerite Germany closer and making a worthy contribution to the common cause of victory over fascism. 


\section{REFERENCES}

1. Archive Morph, f.1299, op.2,d.54,1.44-48, 58-65.

2. World War II history 1939-1945. - M., 1975. T.9.

3. V.A. Zamlinsky At the behest of the international duty - Kiev. 1980.

4. Sworn brothers. - M., 1975.

5. Bakman Ya.I. Warriors of Uzbekistan - participants in the resistance movement in Europe // Social sciences in Uzbekistan. 1973. № 5.

6. Uzbek SSR in the years of GPW. T.3

7. Shishov N.I. In the fight against fascism 1941-1945. (International assistance of the USSR to the peoples of European countries). - M.,1984.

8. Archive Morph, F.1299, op.2, d.53, 1.17-20.

9. Sons of the Country. - Tashkent, 1984.

10. Archive Morph, F.1299, op.2, d.76, 1.10.

11. Truth of the East, 1964, August 28.

12.Semiryaga M.P. Soviet people in European resistance. -M.1970.

13. Kazak V.N. Sworn brothers. Soviet people in the anti-fascist struggle of the peoples of the Balkan countries. 19411945.-M., 1975.

14. Kisselgof I.S. History of France during the Second World War. - M.,1970.

15. Dyadyura L.P. The Uzbeks are participants in the movement of resistance to fascism. Tashkent. 1966.

16. RSASPH, f.553, op.1, d.3, 1.10-12. 